\title{
Peran penerapan Asuhan Neonatus Terintegrasi Terhadap Motivasi dan Kompetensi Mahasiswa serta Kepuasan Pasien di Praktik Klinik Kebidanan
}

\author{
Alfiah Rahmawati, ${ }^{1}$ Nanan Sekarwana, ${ }^{2}$ Achadiyani, ${ }^{3}$ Farid Husin, ${ }^{4}$ Anita D. Anwar, ${ }^{5}$ Meita Dhamayanti, ${ }^{6}$ Ishak \\ Abdulhak $^{7}$ \\ ${ }^{1}$ Mahasiswa Program Studi Magister Kebidanan Fakultas Kedokteran Universitas Padjadjaran \\ ${ }^{2}$ Departemen Ilmu Kesehatan Anakt Fakultas Kedokteran Universitas Padjadjaran \\ ${ }^{3}$ Departemen Biologi Sel Fakultas Kedokteran Universitas Padjadjaran \\ ${ }^{4}$ Departemen Epidemiologi dan Biostatistika Fakultas Kedokteran Universitas Padjadjaran \\ ${ }^{5}$ Departemen Obstetri dan Ginekologi Fakultas Kedokteran Universitas Padjadjaran \\ ${ }^{6}$ Departemen Ilmu Kesehatan Anakt Fakultas Kedokteran Universitas Padjadjaran \\ ${ }^{7}$ Universitas Pendidikan Indonesia
}

\begin{abstract}
Abstrak
Model pembelajaran asuhan neonatus yang mengintegrasikan kebutuhan masyarakat dan pengintegrasian softskill sudah terbukti dapat meningkatkan kompetensi pada pembelajaran dikelas. Mencapai kompetensi tersebut, maka dilakukan pembelajaran di kelas dan di laboratorium, kemudian dilanjutkan dengan praktik di lahan praktik. Sehingga diharapkan asuhan yang diberikan dapat meningkatkan kepuasan pasien, penggunaan asuhan yang berkelanjutan dan meningkatkan kualitas asuhan. Tujuan penelitian ini antara lain menganalisis perbedaan motivasi mahasiswa sebelum dan sesudah penerapan model pembelajaran asuhan neonatus terintegrasi pada praktik klinik kebidanan, menganalisis perbedaan kompetensi mahasiswa sebelum dan sesudah penerapan model pembelajaran asuhan neonatus terintegrasi pada praktik klinik kebidanan, menganalisis hubungan motivasi dengan kompetensi mahasiswa pada praktik klinik kebidanan, dan menganalisis peran kompetensi mahasiswa terhadap kepuasan pasien pada praktik klinik kebidanan. Penelitian ini merupakan studi kuasi eksperimental dengan one group pre test - post test design. Populasi pada penelitian ini adalah seluruh mahasiswa D III Kebidanan semester IV Universitas Sebelas Maret dan pasien yang mendapat asuhan neonatus. Rancangan analisisnya menggunakan uji $\mathrm{T}$ berpasangan dan uji multivariat menggunakan regresi linier dengan bantuan SPSS. Motivasi mahasiswa setelah penerapan model pembelajaran asuhan neonatus terintegrasi berbeda secara bermakna (nilai $\mathrm{p}<0,05$ ) dengan peningkatan 40,48\%, kompetensi (pengetahuan, sikap, dan keterampilan) setelah penerapan model pembelajaran asuhan neonatus terintegrasi berbeda secara bermakna (nilai $\mathrm{p}<0,05$ ) dengan masing-masing prosentase peningkatan adalah kompetensi $36,68 \%$, pengetahuan 30,58, sikap 43,02, keterampilan 42,12. Tidak terdapat hubungan motivasi dengan kompetensi mahasiswa dengan nilai $\mathrm{p}>0,05$. Terdapat peran kompetensi mahasiswa terhadap kepuasan pasien pada praktik klinik kebidanan secara bermakna (nilai $\mathrm{p}<0,05)$. Simpulan penelitian ini terdapat perbedaan motivasi dan kompetensi sebelum dan sesudah penerapan model asuhan neonatus terintegrasi, terdapat peran kompetensi mahasiswa terhadap kepuasan pasien pada praktik klinik kebidanan.
\end{abstract}

Kata Kunci : Asuhan neonatus, model pembelajaran terintegrasi, motivasi, kompetensi, kepuasan pasien 


\begin{abstract}
Therefore requires neonatal care learning model that integrates the needs of society and integration of soft skills, which has been proven to increase competence on class learning. To achieve these outcomes, it has to do integrated learning in the classroom and in the laboratory, then continue to practice at the practice field. So expect care provided can improve patient satisfaction, who use of care sustainable and improve the quality of care. The purpose of this study include analyzing the differences in the motivation of students before and after application of learning models of care neonatal integrated in the clinical practice of midwifery, to analyze differences in competence of students before and after application of learning models of care neonatal integrated in the clinical practice of midwifery, to analyze the relationship between motivation with students' competencies in clinical practice obstetrics, and analyze the role of student competence to satisfaction of patients in clinical practice midwifery. This researche is a study with quasi-experiment one group pre test - post test design. The population in this study were all students of fourth semester D III Midwifery Sebelas Maret University and neonatal patients receiving neonatal care. The draft analysis using paired $\mathrm{T}$ test and multivariate analysis using linear regression with SPSS. Student motivation after the implementation of an integrated learning model of neonatal care were significantly different $(\mathrm{p}<0.05)$ with increase of $40.48 \%$, competencies (knowledge, attitudes, and skills) after the implementation of an integrated learning model of neonatal care were significantly different $(\mathrm{p}<0.05)$ with each percentage increase are knowledge $30,58 \%$, attitudes $43,02 \%$, and skills $42,12 \%$. There was no a correlation motivation and students competence $(\mathrm{p}>0,05)$. There is a correlation competence application to satisfaction of patients in clinical practice midwifery significantly $(\mathrm{p}<0.05)$. The conclusions of this study are there is differences in motivation and competence before and after the application of an integrated model of neonatal care, there is no a correlation motivation and students competence, There is a competence application to satisfaction of patients in clinical practice midwifery significantly.
\end{abstract}

Keywords : Neonatal care, integrated learning, motivation, competence, patient satisfaction

\section{Pendahuluan}

Di Indonesia, bidan adalah tenaga kesehatan yang menjadi bagian dari subsistem Sumber Daya Manusia Kesehatan pada Sistem Kesehatan Nasional (SKN), maka bidan mempunyai tanggung jawab pada terwujudnya SKN, yaitu terbentuknya pembangunan kesehatan masyarakat yang setinggi-tingginya dalam hal pelayanan khususnya kesehatan ibu dan anak. Asuhan kebidanan adalah proses pengambilan keputusan dan tindakan yang dilakukan oleh bidan sesuai dengan wewenang dan ruang lingkup praktiknya berdasarkan ilmu dan kiat kebidanan. Menurut Kepmenkes 369 tentang standar profesi bidan, salah satu kompetensi adalah asuhan neonatus yaitu bahwa bidan memberikan asuhan yang bermutu tinggi, komprehensif pada bayi baru lahir sehat sampai dengan 1 bulan.

Kompetensi bidan akan tercermin pada kinerja bidan saat memberikan pelayanan kesehatan. Kompetensi adalah "seperangkat tindakan cerdas dan penuh tanggung jawab yang dimiliki seseorang sebagai syarat untuk dianggap mampu oleh masyarakat dalam melaksanakan tugas-tugas dalam bidang pekerjaan tertentu. Dalam hal ini kompetensi bidan terdiri dari pengetahuan, sikap, dan keterampilan yang harus dimiliki oleh bidan pada saat melaksanakan praktik kebidanan secara aman dan bertanggung jawab dalam berbagai tatanan pelayanan kesehatan.

Dalam proses pembelajaran motivasi berperan penting dalam menunjang keberhasilan, seseorang yang memiliki motivasi yang kuat cenderung akan melakukan berbagai upaya untuk dapat menguasai bidang yang dipelajarinya, sehingga akan berimplikasi pada pencapaian kompetensi yang dipelajarinya sebagai persiapan memasuki dunia kerja. ${ }^{1,2}$ Penelitian Anggarini 
menyebutkan bahwa motivasi mahasiswa kebidanan di Surakarta 49\% rendah. ${ }^{3}$

Model pembelajaran asuhan neonatus terintegrasi merupakan kerangka kegiatan pembelajaran yang disusun dengan mengintegrasikan/ memadukan berbagai bidang keilmuan yang terkait serta atribut softskill dalam pembelajaran untuk mencapai asuhan kebidanan yang sesuai dengan kebutuhan masyarakat/ pasien berdasarkan kewenangan yang telah ditetapkan untuk profesi bidan. Oleh karena itu diharapkan asuhan yang diberikan bidan dapat meningkatkan kepuasan masyarakat/ pasien, penggunaan asuhan yang berkelanjutan dan meningkatkan kualitas asuhan. ${ }^{4}$

\section{Metode}

Penelitian ini menggunakan metode kuantitatif kuasi eksperimen dengan pre- posttest one group design. Penelitian ini adalah kuasi eksperiment pretest- posttest- one group. Subjek penelitian ini adalah seluruh mahasiswa, dan pasien yang diberi pelayanan oleh mahasiswa DIII Kebidanan semester IV yang memenuhi kriteria inklusi, dan ibu dari neonatus yang mendapat pelayanan asuhan neonatus dari mahasiswa yang bersedia menjadi responden dengan menandatangani lembar persetujuan setelah penjelasan (PSP).

Adapun kriteria dalam penelitian ini adalah : Untuk Mahasiswa mempunyai kriteria inklusi antara lain: mahasiswa prodi DIII Kebidanan UNS semester IV, bersedia menjadi responden dan telah mengisi form persetujuan penelitian. Kriteria sksklusi yaitu mahasiswa yang tidak mengikuti kegiatan evaluasi. Kriteria drop out yaitu mahasiswa yang terpilih sebagai sampel namun kehadiran dalam kegiatan pembelajaran terintegrasi kurang dari $80 \%$.

Untuk Pasien mempunyai kriteria inklusi yaitu pasien yang bayinya diberikan asuhan neonatus terintegrasi oleh mahasiswa kebidanan UNS semester IV, bersedia menjadi responden dan telah mengisi form persetujuan penelitian. Kriteria Eksklusi yaitu pasien yang tidak berada dalam satu ruangan dengan neonatusnya.

Analisis statistik yang digunakan yaitu : analisis perbedaan nilai awal (pre test) dan nilai akhir (post test) motivasi mahasiswa pada penerapan model pembelajaran asuhan neonatus terintegrasi. Uji statistik yang digunakan adalah uji Wilcoxon karena data tidak berdistribusi normal. Analisis perbedaan nilai awal dan nilai akhir kompetensi mahasiswa pada penerapan model pembelajaran asuhan neonatus terintegrasi. Uji statistik yang digunakan adalah adalah uji Wilcoxon karena data tidak berdistribusi normal kecuali pada data perbedaan pengetahuan mahasiswa menggunakan uji $\mathrm{t}$ berpasangan karena data berdistribusi normal. Analisis hubungan motivasi dengan kompetensi mahasiswa pada praktik klinik kebidanan menggunakan uji Chi Kuadrat Analisis peran kompetensi mahasiswa terhadap kepuasan pasien pada praktik klinik kebidanan menggunakan uji Multiple Regresi (Regresi Logistik).

Pada penelitian ini, mahasiswa mendapat perlakuan berupa pengkayaan asuhan neonatus terintegrasi selama 4 minggu. Pengukuran pre test motivasi dan kompetensi, dilakukan sebelum diberikan perlakuan. Pengukuran post test motivasi dan pengetahuan dilakukan setelah mahasiswa mendapat perlakuan. Pengukuran sikap, dan keterampilan mahasiswa dilakukan bersamaan dengan penilaian kepuasan pasien, yaitu saat mahasiswa melakukan praktik klinik kebidanan.

\section{Hasil}

\section{Tabel 1 Karakteristik Subjek Penelitian}

Distribusi karakteristik mahasiswa berdasarkan indeks prestasi dan motivasi sebelum diberikan perlakuan dapat dilihat pada tabel sebagai berikut

\begin{tabular}{lcc}
\hline \multicolumn{1}{c}{ Karakteristik } & $\begin{array}{c}\mathrm{n} \\
\text { (jumlah) }\end{array}$ & $\begin{array}{c}\text { Presentase } \\
(\%)\end{array}$ \\
& & \\
\hline Indeks Prestasi Kumulatif & & \\
$\quad 3,51-4,00$ & 3 & 8,1 \\
$3,01-3,51$ & 22 & 59,5 \\
$\quad 2,76-3,00$ & 8 & 21,6 \\
$\quad<2,75$ & 4 & 10,8 \\
Motivasi Sebelum & & \\
Perlakuan & & \\
$\quad$ Baik & & \\
$\quad$ Kurang Baik & 23 & 62,2 \\
\hline
\end{tabular}

Dari tabel 1 di atas menunjukkan bahwa IPK mahasiswa program studi D III Kebidanan UNS mayoritas 3,01-3,51 sebanyak 22 mahasiswa dan sebagian besar mempunyai motivasi yang tinggi yaitu sebanyak 23 mahasiswa. 
Tabel 2 Perbandingan Motivasi Sebelum dan Sesudah Perlakuan Pembelajaran Asuhan Neonatus Terintegrasi

\begin{tabular}{llll}
\hline \multicolumn{1}{c}{ Komponen } & \multicolumn{1}{c}{ Sebelum $(\mathbf{n}=\mathbf{3 7})$} & \multicolumn{1}{c}{ Sesudah $(\mathbf{n}=\mathbf{3 7})$} & \multicolumn{1}{c}{ Nilai $\mathbf{p}^{*}$} \\
\hline $\begin{array}{l}\text { Motivasi } \\
\text { Rerata }(\mathrm{SD})\end{array}$ & $57,2(12,59)$ & $77,8(4,60)$ & $<\mathbf{0 , 0 0 1}$ \\
Median & 52 & 76 & \\
Rentang & $42,67-84,00$ & $72-92$ & \\
\hline Keterangan: * Wilcoxon Signed Rank & &
\end{tabular}

Motivasi mahasiswa setelah penerapan model berbeda secara bermakna $(p<0,05)$ dengan pembelajaran asuhan neonatus terintegrasi peningkatan $40,48 \%$.

Tabel 3 Perbandingan Pengetahuan, Sikap, dan Ketrampilan Sebelum dan Sesudah Perlakuan Pembelajaran Asuhan Neonatus Terintegrasi

\begin{tabular}{|c|c|c|c|c|}
\hline Komponen & Sebelum $(n=37)$ & $\begin{array}{c}\text { Sesudah } \\
(\mathbf{n}=37)\end{array}$ & Nilai $\mathbf{p}^{*}$ & $\begin{array}{l}\text { Rata-rata \% } \\
\text { Peningkatan }\end{array}$ \\
\hline Pengetahuan & & & $<0,001$ & 30,58 \\
\hline Rerata (SD) & $70,05(11,25)$ & $88,86(11,09)$ & & \\
\hline Median & 73 & 93 & & \\
\hline Rentang & $47-87$ & $53-100$ & & \\
\hline Sikap & & & $<0,001$ & 43,02 \\
\hline Rerata (SD) & $62,16(14,75)$ & $86,49(17,03)$ & & \\
\hline Median & 60 & 100 & & \\
\hline Rentang & $40-80$ & $60-100$ & & \\
\hline Ketrampilan & & & $<0,001$ & 42,12 \\
\hline Rerata (SD) & $63,78(10,37)$ & $89,19(15,34)$ & & \\
\hline Median & 60 & 100 & & \\
\hline Rentang & $40-80$ & $60-100$ & & \\
\hline Kompetensi & & & - & 54,05 \\
\hline Kompeten & $\mathbf{0}$ & 20 & & \\
\hline Tidak Kompeten & 37 & 17 & & \\
\hline
\end{tabular}

Keterangan: * Wilcoxon Signed Rank

Berdasarkan tabel 3 diatas terlihat adanya perbedaan pengetahuan, sikap dan ketrampilan antara sebelum dan sesudah perlakuan menggunakan modul pembelajaran terintegrasi. Penerapan asuhan neonatus terintegrasi terbukti

dapat meningkatkan kompetensi mahasiswa secara keseluruhan, terbukti sebelum diberikan pembelajaran terintegrasi tidak ada seorang mahasiswa pun yang kompeten, namun setelah dilakukan intervensi, terdapat 20 orang mahasiswa yang kompeten

Tabel 4 Analisis Hubungan Motivasi dengan Kompetensi Mahasiswa

\begin{tabular}{lrrrrr}
\hline & Kompeten & \multicolumn{2}{c}{ Tidak Kompeten } & $\mathrm{p}^{*}$ \\
& $\mathrm{n}$ & $\%$ & $\mathrm{n}$ & $\%$ & \\
\hline Tinggi & 12 & 50 & 12 & 50 & 0,452 \\
Rendah & 8 & 61,5 & 5 & 38,5 & \\
\multicolumn{1}{c}{ Total } & 20 & 54,1 & 17 & 45,9 & \\
\hline Ketal
\end{tabular}

Keterangan: * Chi Square 
Pada tabel 4 tampak bahwa tidak ada hubungan antara motivasi dengan kompetensi mahasiswa dengan $(p>0,05)$. Peran kompetensi mahasiswa terhadap kepuasan pasien dilakukan analisis regresi logistik berikut :

Tabel 5 Analisis Regresi Logistik Kompetensi Mahasiswa terhadap Kepuasan Pasien

\begin{tabular}{lllll}
\hline & \multicolumn{1}{c}{ Variabel } & \multicolumn{1}{c}{ Koefisien } & \multicolumn{1}{c}{$\mathrm{p}$} & \multicolumn{1}{c}{ OR (IK95\%) } \\
\hline Model awal & Kompetensi & $-20,22$ & 1,00 & $0,00(0,00-)$. \\
& Kognitif & 21,20 & 1,00 & $1615475593(0,00-)$. \\
& Ketrampilan & 23,60 & 1,00 & $17770231527(0,00-)$. \\
\multirow{4}{*}{ Model akhir } & Konstanta & $-23,60$ & 1,00 & 0,00 \\
& Sikap & 3,342 & 0,003 & $5,55(3,06-261,87)$ \\
& Konstanta & $-2,40$ & 0,022 & 0,09 \\
\hline
\end{tabular}

Berdasarkan tabel 5 diatas, menunjukkan bahwa dari model kompetensi (pengetahuan, sikap, keterampilan) yang paling berperan

\section{Diskusi}

Pada tabel 4.3 menunjukkan bahwa nilai median dan rentang dari setelah perlakuan menjadi lebih tinggi dari pada sebelum perlakuan. Pada nilai motivasi didapatkan prosentase peningkatan sebesar 40,48\%. Berdasarkan hasil uji statistik nilai $\mathrm{p}<0,05$ sehingga terdapat perbedaan nilai sebelum dan sesudah pemberian model pembelajaran terintegrasi pada praktik klinik kebidanan.

Dalam penelitian ini mahasiswa menggunakan model belajar yang berbeda dari sebelumnya yang masih menggunakan model pembelajaran konvensional. Pada pembelajaran terintegrasi membentuk keaktifan siswa didalam pembelajaran untuk mencapai hasil belajar maksimal dengan mempertimbangkan relevansi terhadap kebutuhan mahasiswa dalam praktik klinik sehingga mahasiswa dapat percaya diri dan puas pada hasil belajarnya dikarenakan penerapan model pembelajaran menggunakan metode kasus yang mahasiswa dituntut untuk memecahkan masalah secara holistik dan langsung berhubungan dengan pengalaman yang sesungguhnya. Oleh karena itu sesuai dengan tujuan dari pembelajaran terintegrasi yaitu salah satunya meningkatkan minat dan motivasi peserta didik.Pada tabel 4.3 menunjukkan bahwa nilai kompetensi, pengetahuan 30,58, sikap 43,02, keterampilan 42,12. Berdasarkan hasil uji statistik nilai $p<0,05$ sehingga terdapat perbedaan nilai sebelum dan sesudah pemberian model pembelajaran terintegrasi pada praktik klinik kebidanan. terhadap kepuasan pasien adalah sikap, dan sikap mahasiswa mempunyai kemungkinan 5,5 kali membuat pasien puas.

Hasil penelitian tersebut sejalan dengan penelitian yang dilakukan Pipas, menunjukkan bahwa penerapan kurikulum terintegrasi pada primary care medical school dapat meningkatkan kemampuan peserta didik dalam memberikan pelayanan yang berbasis komunitas. Dengan pembelajaran terintegrasi, peserta didik telah dibiasakan untuk mempelajari suatu pengetahuan berdasarkan konteks yang nyata, maka ketika melakukan pembelajaran langsung di komunitas tidak memerlukan waktu yang lama untuk penyesuaian dan mengaplikasikannya. ${ }^{5-8}$ Dalam studi Nova menunjukkan adanya pengaruh model pembelajaran asuhan neonatus terintegrasi terhadap kompetensi mahasiswa sebesar 12,48 kali. ${ }^{9}$

Penelitian lain yang dilakukan Paley menunjukkan bahwa dengan diterapkannya Integrating Case Topic pada pendidikan dokter, mampu meningkatkan pengetahuan dan ketrampilan peserta didik pada kasus yang diajarkan maupun ilmu dasar yang mendasari untuk kasus tersebut. Penelitian ini menguatkan penelitian yang dilakukan Ghosh tentang Integrated Learning Program, bahwa penerapan pembelajaran terintegrasi dapat meningkatkan penguasaan pengetahuan beberapa ilmu dasar yang membangun model terintegrasi dan meningkatkan keterampilan praktik klinik. Pada model pembelajaran ini tidak hanya mengintegrasikan tema-tema ilmu dasar, namun juga mengintegrasikan berbagai metode pembelajaran yang bertujuan untuk memicu pembelajaran aktif peserta didik, keterampilan analisis dan clinical reasoning. Melalui 
pengintegrasian metode pembelajaran ini, secara efektif dapat memudahkan peserta didik saat melakukan praktik klinik. ${ }^{10,11}$

Studi oleh Chien-Yun memperlihatkan setelah diberikan model pembelajaran yang diintegrasikan pencapaian nilai kognitif yang bermakna $(\mathrm{p}<0,05)$. Pembelajaran terintegrasi mampu menciptakan attitude yang positif terhadap pembelajaran. Melalui sikap pembelajaran yang positif akan memicu mahasiswa meningkatkan kemauan dalam pengembangan pengetahuannya. ${ }^{12}$

Hasil penelitian menunjukkan model pembelajaran asuhan neonatus terintegrasi mampu meningkatkan nilai sikap mahasiswa sebesar $43,02 \%$ dan keterampilan mahasiswa sebesar $42,12 \%$. Hasil tersebut didukung dengan penelitian yang dilakukan oleh Doraisamy, dkk dan Kate, dkk yang menyatakan bahwa pengajaran terintegrasi pada mahasiswa kedokteran tidak hanya mampu meningkatkan nilai kognitif tetapi juga psikomotorik. ${ }^{13}$

Penilaian kompetensi dalam penelitian ini didasarkan pada standar yang ditentukan oleh BPPSDM. Hal ini didasarkan pada tujuan penelitian yaitu untuk memenuhi kebutuhan masyarakat. Hasil penelitian post test menunjukkan mayoritas mahasiswa 20 dari 37 mahasiswa mencapai kompetensi. Selain dari peningkatan nilai kompetensi sebelum dan sesudah penerapan asuhan neonatus terintegrasi sebesar 36,68\%, pada tabel 4.4 menunjukkan bahwa indeks prestasi tidak mempengaruhi pencapaian kompetensi (nilai $\mathrm{p}>0,05$ ), hasil tersebut semakin memperkuat bahwa ketercapaian kompetensi mahasiswa dari penerapan model pembelajaran asuhan neonatus terintegrasi, kemudian faktor yang mendukung ketercapaian kompetensi mahasiswa adalah pengambilan nilai post test (sikap dan keterampilan) pada praktik klinik kebidanan yang kedua sehinga mahasiswa sudah pernah melakukan praktik klinik kebidanan sebelumnya.

Berdasarkan hasil analisis menunjukkan bahwa tidak terdapat hubungan motivasi dengan kompetensi mahasiswa. Hal ini berbeda dengan teori sebelumnya yang menunjukkan bahwa motivasi berhubungan dengan pencapaian kompetensi mahasiswa, hal ini disebabkan motivasi bukan satu-satunya faktor yang dapat meningkatkan kompetensi mahasiswa. Model pembelajaran asuhan neonatus terintegrasi merupakan bagian dari pembentukan motivasi secara ekstrinsik, sedangkan dalam pencapaian kompetensi yang sangat berpengaruh adalah motivasi dari intrinsik dari mahasiswa itu sendiri. Terlihat dari data yang menunjukkan dari 20 mahasiswa yang kompeten tidak semuanya dari mahasiswa yang mempunyai motivasi tinggi, akan tetapi juga terdapat dari mahasiswa yang mempunyai motivasi rendah. Selain dari faktor internal yang telah disebutkan, didapatkan satu faktor yang menentukan hasil belajar dalam mencapai kompetensi peserta didik yaitu pengetahuan awal peserta didik (prior knowledge). ${ }^{14}$

Tabel 4.7 menunjukkan bahwa dari model kompetensi (pengetahuan, sikap, keterampilan) yang paling berperan terhadap kepuasan pasien adalah sikap, dengan nilai $\mathrm{p}<0,05$. Sikap mahasiswa mempunyai kemungkinan 5,5 kali membuat pasien puas terhadap asuhan neonatus yang diberikan mahasiswa. Analisis lebih lanjut menunjukkan kepuasan pasien setelah diberikan asuhan neonatus terintegrasi oleh mahasiswa sebanyak 20 orang $(54,1 \%)$. Dalam hal ini tidak semua pasien yang puas dilayani oleh mahasiswa yang kompeten, akan tetapi juga terdapat dari mahasiswa yang tidak kompeten.

Sikap mahasiswa mempunyai peranan yang paling kuat terhadap pelayanan pasien sehingga pasien puas dengan asuhan yang telah diberikan. Sesuai dengan hasil penelitian yang menunjukkan sikap mampu membuat pasien puas sebanyak 5,5 kali kemungkinan. Hal ini dimungkinkan karena pada pembelajaran asuhan neonatus terintegrasi dibangun berdasarkan hardskill dan softskill yang dibutuhkan pada kasus neonatus dalam praktik klinik, yang selama ini pada model pembelajaran diberikan secara terkotak-kotak atau terpisahpisah tidak menjadi satu kesatuan.

Berdasarkan penelitian Anjaryani yang dilakukan pada kelompok perawat, kemudahan dalam melakukan hubungan komunikasi yang baik, perhatian pribadi dan memahami kebutuhan pasien adalah sebagai pelanggan dan bertindak demi kepentingan pasien. Wujud empati tercermin dalam perilaku perawat, modal perawat terletak pada keramahan dan kesabaran dan tujuannya untuk meringankan beban pasien sehingga perasaan pasien jauh lebih baik dari sebelumnya, menekankan bahwa mereka (antara pasien dan perawat) akan bersama melalui segala sesuatunya demi kesembuhan pasien. Perawat dengan senyum, salam, sapa serta sopan santunnya bisa membangkitkan inisiatif pasien 
untuk sembuh, sehat, perhatian, tidak menyepelekan mereka serta menjadikan pasien sebagai orang yang dihargai. ${ }^{15-18} 19$

\section{Simpulan}

Simpulan penelitian ini terdapat perbedaan motivasi dan kompetensi sebelum dan sesudah penerapan model asuhan neonatus terintegrasi, terdapat peran kompetensi mahasiswa terhadap kepuasan pasien pada praktik klinik kebidanan.

\section{Daftar Pustaka}

1. Lim DH. Motivation and learner characteristics affecting online learning and learning application. J Educational technology systems. 2003;31(4):423-39.

2. Pintrich PR. A motivational science perspective on the role of student motivation in learning and teaching contexts. Journal of Educational Psychology. 2002;95(8):667-86.

3. Anggarini S. Pengaruh Motivasi Belajar dan Metode Pembelajaran Studi Kasus terhadap Prestasi Belajar Penggunaan Partograf Mahasiswa Akademi Kebidanan di Surakarta Universitas Sebelas Maret Surakarta; 2012.

4. Creel LC SJ, Yinger NV. Client-Centered Quality : Client's Perspective and Barriers to Receiving Care. Population Reference Bureau. 2002:1-8

5. Pipas CF PD, Fall LH, Olson AL, Mahoney JF, Skochelak SE, et al. Collaborating to Integrate Curriculum in Primary Care Medical Education : Successes and Challenges from Three US Medical Schools. Family Medicine. 2004;36:S126-S32.

6. Drake SM. Menciptakan Kurikulum Terintegrasi yang Berbasis Standar Seri Standar Kurikulum Inti. Jakarta: PT Indeks; 2012.

7. Cooper H CC, Gibbs T, Watkins C. Developing an Evidence Base for Interdisciplinary Learning : Systematic Review. J Adv Nurs. 2001 Jul;35 (2):228-37.

8. ER; TJSJN. Pioneering a Universal Curriculum : a look at six disciplines involved in women's health care. J Midwifery Womens Health. 2009 Jul-Aug;54(4):306-13.

9. Yulianti N. Pengaruh Penerapan Model Pembelajaran Asuhan Neonatus Terintegrasi terhadap Peningkatan Kompetensi Mahasiswa
DIII Kebidanan. Bandung: Prodi Magister Kebidanan Pascasarjana FK UNPAD; 2014.

10. Paley B; O'Connor MJ; Baillie SJ; Guiton G; Stuber ML. Integrating Case Topics in Medical School Curriculum to Enhance Multiple Skill Learning : Using Fetal Alcohol Spectrum Disorders as an Exemplary Case. Academic Psychiatry. 2009;33:143-8.

11. Ghosh S; Pandya HV. Implementation of Integrated Learning Program in Neurosciences during First Year of Traditional Medical Course : Perception of Students and Faculty. BMC Medical Education. 2008;8 (44):1-8.

12. Chien-Yun D, Wan-Fei C, Yu-Hsi Y, Chia-Hung Y. A study on Modification of Knowledge, Attitude and Practise on Vocational High School Electronics Courses Integrated with Nanotechnology Concept. Int $\mathbf{J}$ of Thermal \& Environmental Engineering. 2012;4(1):73-9.

13. Doraisamy R, Radhakrishnan S. The Effectiveness of Integrated Teaching Over Traditional Teaching Among First Year MBBS studets : A preliminary Study. Medical Jurnal of DrDYPatil University. 2013;6(2):139-41.

14. Prastisi TD. Pengaruh pendekatan pembelajaran RME dan pengetahuan awal terhadap kemampuan komunikasi dan pemahaman matematika siswa SMP kelas VII. Jurnal Didaktika. Maret 2007;2(1).

15. Anjaryani WD. Kepuasan Pasien Rawat Inap terhadap Pelayanan Perawat di RSUD Tugu Semarang. Program Pasca Sarjana Universitas Diponegoro Semarang. 2009.

16. Saha, Parmita, Zhao, Yanni. Relationship Between Online Service Quality And Customer Satisfaction A study in Internet BankingMaster'Thesis :083 SHU. ,2005.

17. Harcar, Kara, Kucukemiroglu. "Consumer's Perceived Value and Buying Behavior of Store Brand: And Empirical Investigation. The Business Review. 2006;5(2).

18. Johansson P, Oleni M, Fridlund B. Patient satisfaction with nursing care in the context of health care : a literature study. Nordic college of caring sciences Scand J Caring Sci. 2002.

19. Makoul G, Krupat E, Chang C-H. Measuring patient views of physician communication skills : Development and testing of the communication assesment tool Patient education and counseling Elsevier. 2007;67:333-42. 